Leonid Antonovych Vyhovskyi, Dr Hab., Prof.,

Nataliia Stefanivna Kulish, PhD

Leonid Yuzkov Khmelnytskyi University of Management and Law, Khmelnytskyi, Ukraine

\title{
RELIGION AS AN IMPORTANT FACTOR OF THE MODERN UKRAINIAN POLITICAL REALITY
}

The paper analyses the place and role of religion in the political life of modern Ukraine and its influence on the political life and transformations broght about by political factors. It shows that the growing level of believers' political activity determines the deepening of the process of politicization of religion and simultaneously contributes to the religionization of the political process. It demonstrates that the politicization of religion encourages the laity and the clergy to build and establish a democratic Ukrainian state and the revival of national spirituality and morality. But, on the other hand, in the presence of anti-Ukrainian tendencies in the activities of certain denominations such a process can lead to a sharp political and inter-church confrontation which can cause a political and religious crisis in society. It is shown that some activities of religious organizations operating in Ukraine are outside of the legal framework. The need to align the existing legal framework on the relationship between the Church, religious organizations and the state with modern realities is emphasized. In this context, the problem of developing and implementing deterrent mechanisms for the participation of extremist religious organizations in political activities is quite relevant.

It is shown that a starting point for the involvement of religious organizations and institutions in political activities deals with understanding (at the theoretical and theological level) of the principles of their interactions with the structures of state authorities, society and citizens. This is achieved by way of incorporating findings of theological and canonical research on such topics in the strategy, social concepts, appeals. This serves as the basis for specific instructions regarding the forms and content of participation of the Church, clergy, and laity in political life.

It is emphasized that the direct inclusion of the Church, religious denominations and believers in political processes opens the possibility for manipulative influence on believers aiming at lobbying interests of certain political parties during the election processes.

Keywords: religion, Church, confession, social concept, democracy, civil society, politics, political manipulations, state.

удк 316.6

DOI: $10.17721 /$ sophia.2020.16.2

К. Говорун, д-р фрілос. наук, профр. Стокгольмська школа теології, Стокгольм, Швеція ORCID: 0000-0002-7927-6995

Scopus Author ID: 56721422300 e-mail: CyrilHovorunhovorun@gmail.com

\section{ДОБРІ І ЛИХІ БОГОСЛОВСЬКІ ПЛОДИ ПАНДЕМІї}

Досліджено різні підходи до пандемії COVID-19 як у світовому, так і в українському православ 'ї, зокрема, ідентифріковано фідеїстичне і реалістичне ставлення до євхаристії та до можливості передачі вірусів через неї. Перший підхід відкидає, а другий підтверджує ризик зараження коронавірусом через причастя. Обговорено різні можливості та форми богослужіння через інтернет, зокрема контроверсійну практику відправлення літургії через комунікаційні платформи. Запропоновано оновлену форму давньої агапи - трапези любові, що супроводжувала євхаристію в ранній церкві. Також заадано давні та сучасні форми причащання, з посиланням на дослідження о. Роберта Taфma, SJ. Темою дослідження також є так зване ковід-дисидентство, коли люди недооцінюють або взагалі відкидають ризики та заходи із запобігання поширенню інфекції. Цей різновид дисидентства популярний серед православних фундаменталістів та консерваторів, зокрема і в Україні. Серед іншого наведено два випадки ковід-дисидентства - від колишніх митрополитів київських Онуфрія (Березовського) та Філарета (Денисенка). Стверджуємо, що ставлення до COVID-19, яке пропагують ці та інші ієрархи, подібне до середньовічних "випробувань через страждання", коли підозрюваних у злочині випробовували тим, що вони голими руками виловлювали кільце з окропу або переносили на відстань розпечене залізо. Ïх вважали невинними лише тоді, коли вони залишалися неушкодженими. Подібне ставлення до тих, хто постраждав від COVID-19, призводить до їхньої стигматизації та віктимізації.

Ключові слова: євхаристія, фідеїзм, COVID-19, агапа, випробовування через страждання, фундаменталізм.

Криза, що була спровокована коронавірусною хворобою, яку ми у статті будемо називати ковідом, викликала розгубленість серед богословів та у помісних православних церквах. Багато ієрархів і кліриків цих церков досі не визначилися, або й не знають, що казати своїй пастві з приводу ризиків, пов'язаних із цією хворобою. Багато з них самі вже нею перехворіли, а деякі й померли. Водночас пандемія спровокувала дискусії, які можуть бути дуже продуктивними з погляду подальшого розвитку богослов'я і соціальних доктрин різних церков. Через рік після початку пандемії можна спостерігати зародження нових богословських та етичних ідей, а також критичне переосмислення усталених догм. ${ }^{1}$

Фахівці, зокрема, ретельно обговорюють проблеми, пов'язані зі здійсненням євхаристії й участю вірних у цьому таїнстві. Левова частка богословських реакцій на тему коронавірусу стосується саме євхаристії. Утім, у цьому немає нічого дивного, адже основною рамкою сучасного православного богослов'я стала саме евхаристійна еклезіологія.

Одна з головних богословських проблем, пов'язаних із євхаристією в епоху пандемії, - це можливість передавання інфекції через євхаристійні дари. Думки з цього

\footnotetext{
${ }^{1}$ Стаття друкується в авторській редакції.
}

приводу розділилися: для когось таке передавання інфекції неможливе апріорі, а для інших - можливе і тому становить реальну загрозу здоров'ю та життю людей. На захист першої позиції висловилися переважно офіційні церковні структури. Синод Елладської православної церкви, зокрема, опублікував 9 березня 2020 р. офріційна комюніке, де заявив таке: Для членів церкви підхід до Євхаристії і причастя від Загальної Чаші Життя, безумовно, не може бути причиною передачі хвороби, оскільки вірні в усі часи знали, що підхід до Святого Причастя, навіть посеред пандемії, з одного боку, $є$ практичним підтвердженням самовіддачі Живому Богові, а з іншого - великим виявом любові, що долає будьякий людський i, можливо, навіть виправданий страх: "У любові немає страху, але досконала любов проганяє страх" (1 Івана 4:18). Члени церкви знають, що причастя, тобто відносини, є плодом любові і свободи - саме через те, що йому невідомі підозри, сумніви і страхи [9].

Цю й подібні їй позиції можна вважати фрідеїстичними, тобто такими, що апелюють тільки до постулатів віри [13]. Поки що в активі прихильників фідеїстичного підходу немає значущих богословських рефлексій на тему невразливості євхаристії для коронавірусу. Вони обмежуються переважно закликами вірити в таку невразливість. Кращі справи в іншої групи богословів, які вважа- 
ють, що вірус може передаватися через євхаристійну чашу. Цю групу можна назвати реалістичною, оскільки її члени вважають, що реальність євхаристійних тіла і крові Христа передбачає: євхаристійні дари підкоряються фізичним законам, а тому здатні передавати інфекцію.

Богословський доробок євхаристійних реалістів наразі вагоміший за внесок фідеїстів. Саме з позицій євхаристійного реалізму, зокрема, видано збірку "Церква в період пандемії". Ії упорядниками стали професор Фессалонікійського університету Петрос Васіліадіс та професор Фордамського університету в Нью-Йорку Джордж Демакопулос. Низка важливих публікацій з'явилася й у блозі "Публічне Православ'я", редагованому тим самим Джорджем Демакопулосом й Арістотелем Папаніколау із Центру православних християнських досліджень Фордамського університету. Серед тематичних публікацій у цьому блозі можна виокремити такі: "Цінність поняття "нічого". Уроки Covid-19 щодо мовчання і спокою" за авторства богословського радника Вселенського патріарха Варфоломія диякона Іоанна Хрісавгіса, "Бог, зло та Covid-19" за авторства проф. Павла Гаврилюка, "Готові для вакцини проти ковіду? Православна перспектива" за авторства проф. Ґейл Волощак (професори П. Гаврилюк і Ґ. Волощак працюють в американських університетах і мають українське коріння), "Рефлексії щодо віри і науки у світлі Covid-19" та "Євхаристія, їі фізичні елементи і молекулярна біологія" Герміни Неделеску. Усіх згаданих авторів можна віднести до групи євхаристійних реалістів.

У тому самому блозі автором цієї статті був опублікований матеріал "Covid-19 і християнський (?) дуалізм". Основна думка публікації полягає в тому, що вірус $є$ частиною Божого творіння й, отже, входить до загального план порятунку через recapitulatio у Христі. 3 цієї позиції його не можна розглядати як певне суще зло - такий погляд був би дуалістично-маніхейським. Саме як частина Божого творіння, коронавірус може безперешкодно перебувати в євхаристійних дарах і передаватися через них людині.

3 погляду євхаристійного реалізму, евхаристійний фідеїзм, принаймні в тому вигляді як його нині сформульовано, межує з певним магізмом. Критику фідеїзма, що її було озвучено в різних публікаціях, можна звести до таких пунктів:

1. Євхаристійні дари не є магічним антисептиком, що знищує інфекцію. Вони - частка фізичного світу й у своєму матеріальному вимірі підпорядковуються його законам. Думати інакше - це по суті підтримати докетичну позицію, що розглядає людське єство Христа як виключення з рамок матеріального світу.

2. В історії були засвідчені випадки навмисного або ненавмисного отруєння євхаристійний дарами. 3 огляду на це євхаристія може передавати отруйні та шкідливі речовини, серед яких можуть бути і віруси.

3. Церква в минулому часто зіштовхувалася з епідеміями і запроваджувала санітарні заходи проти поширення інфекцій через чашу. Отже, вона непрямо визнавала можливість зараження через євхаристійні дари.

4. Церква також традиційно вживає заходів проти псування євхаристійних дарів. Вона, наприклад, вимагає від священнослужителів берегти їх від плісняви.

5. Крім того, на думку євхаристійних реалістів, фідеїстична позиція близька до вчення афтартодокетів. Це була доктрина, що виникла всередині антихалкідонської партії наприкінці п'ятого століття і була сформульована Юліаном Галікарнаським [8]. Згідно з цим ученням, людство Христа не підлягало тлінності ( див з передумови, загальної для всіх антихалкідонітів, що божество і людство Христа є єдиною природою. 3 цієї передумови Юліан робив висновок, що божество і людство мають спільні властивості, зокрема і властивість нетління. 3 погляду євхаристійного реалізму, сучасні євхаристійні фідеїсти виходять з подібного афтартодокетичного бачення Боговтілення.

Найзапекліші богословські дискусії на тему ковіду точаться довкола практичних питань. Одна з них - про можливість здійснення таїнств, насамперед євхаристії, у режимі онлайн. Це питання, зокрема, постало всередині Православної церкви України. Її клірик Ігор Сава у травні 2020 р. повідомив на своїй сторінці у фейсбуці, що в умовах карантину здійснює літургію для своїх парафіян у режимі онлайн: 3 початку карантину служимо літургії онлайн. Щоб заповнити брак причастя, розмірковували про духовне причастя (адже воно насправді не $€$ матеріальним), пробували розвозити парафіянам запасні дари, але не завжди і не для всіх це доступно. Увесь цей час я думав, а чому не можна зробити онлайн-літургію повноцінною? Ми молимося про те, щоб цей хліб і це вино стали Тілом і Кров'ю Христа і зробили нас причетними Йому, аби ми стали Його Тілом. Невже ця молитва не "діє" на відстані? Може, радіохвилі (Wi$\mathrm{Fi})$ або використання гаджетів $є$ перешкодою на шляху нашого об'єднання навколо Христа, Його животворячих Тіла і Крові? Минулої суботи мав дивовижний досвід співслужіння повноцінної літургії з причастям за допомогою програми для відеоконференцій Hangouts, яку організував і яку очолював о. Дмитро Вайсбурд. Кожен з учасників богослужіння приготував перед монітором хліб, вино і воду. Служили літургію Іоанна Златоуста, по черзі читаючи і співаючи частини служби. Освячення Дарів відбувалося так само, як і під час богослужіння в храмі. Усі учасники причастилися, кожен у своєму помешканні. Це було дивовижне і надихаюче богослужіння [4].

Детальніше свою логіку о. Ігор Сава пояснив у коментарі, який він надав порталу Cerkvarium.org:

3 книг ми знаємо, що літургія перекладається як "спільна справа". А чим вона є насправді? Якщо уважно придивитися, не тільки спільної справи, а й єдиної служби ми не знайдемо. Їх служиться відразу кілька, причому в різних приміщеннях. У вівтарі, за закритими дверима і засунутою для надійності щільною завісою служиться та сама Євхаристія, де всі, в кращому випадку, зібрані навколо трапези Господньої. У церкві в цей час служать пісенне послідування, в якому так мало молитви, що колись довелося спеціально додати заамвонну молитву, що представляє для мирян короткий зміст літургії. У дияконів своя служба - театральне дійство, у якому бічні двері давно сприймаються як куліси, катапетасма як завіса, а паламарі як костюмери з реквізиторами. На кулісах, вибачте, дверях іконостасу, навіть дзеркала вішають зі зворотного боку, щоб той, хто виходить до публіки, міг перевірити свій грим. Я вже не кажу про реєстраторів і кіоск, які служать свою службу в цьому ж місці. У цій дії $€$ все, важко знайти тільки справу, спільну для всіх. <...>

Якщо літургію знову зробити спільною справою, як це було в давнину, зробити доступними для всіх учасників і таїнство, і співи, і символи, щоб все це існувало в службі не паралельно (що, до речі, заборонено соборами), а послідовно, то людям, які переживають таку дію, буде мало просто дивитися літургію в трансляції, у разі якщо вони не можуть прийти в храм. Вони захочуть переживати її. Не поклонятися, а служити. <...>

Чи може Господь відповісти на євхаристійну молитву на відстані? Так і відбувається на кожній літургії. Головне, щоб серед вірних ця молитва була, щоб вони знали, бачили і чули один одного, мали загальне прагнення. До речі, в храмі цього не завжди можна досягти [2]. 
Проте зазначений літургійний експеримент не знайшов підтримки як з боку єпископату ПЦУ, так і з боку богословів цієї церкви. Клірик ПЦУ прот. Андрій Дудченко оприлюднив власні полемічні зауваження щодо літургії онлайн і серед іншого зазначив: Чи є це дійство "спільною справою" (адже так перекладається слово "літургія")? Чи є це подією, у якій беруть участь тільки учасники, а не спостерігачі? На перший погляд видається, що так. Ті, хто приєдналися до відеоконференції, мали намір разом звершити літургію і причаститися. Ба більше, на відміну від звичайного нам порядку проведення літургії у храмі, тут учасники теоретично мали можливість чути всі молитви, які промовляє очолюючий богослужіння пресвітер, та свідомо розумом приєднуватися до молитви, а також відповідати "амінь". Тоді чого ж бракує? Бракує якраз спільності, що можлива при фрізичному перебуванні учасників поруч в одному просторі. Літургія - це не "технічний засіб" заради освячення хліба і вина, так би мовити, отримання матеріальної святині, якою потім можна освятитися. Це - спілкування, спільність, єдність, кульмінацією якої стає те, що всі учасники причащаються одного Тіла і Крові Христових. Важливим $€$ не тільки момент причащання, а усе, що громада здійснює на цій службі разом. У служінні онлайн бракує тілесної присутності [6].

У ролі альтернативи "євхаристії онлайн" було здійснено спробу відновити давню практику так званих агап. Агапи або вечері любові часто практикували у древній церкві $[14,10,11]$. Вони самі по собі не були євхаристією, але часто супроводжували євхаристію у ролі спільної трапези членів церковної громади. Подібні агапи почали звершувати в онлайн режимі і в період пандемії. Автор пропонованої статті, зокрема, звершував такі агапи разом 3 інокинею Вассою (Ларіною). Водночас учасники агапи перебували на різних континентах i зв'язувалися один з одним через платформу Zoom. Iнокиня Васса, яка $€$ фахівцем в галузі літургіки, створила структуру агапи для здійснення ії онлайн. Наведемо тут цю структуру повністю, тому що вона викликає богословський і літургійний інтерес:

Світла П'ятниця, 24 квітня 2020 р.; 10:00 за ньюйоркським часом; 7:00 ранку за каліфорнійським часом; 15:00 за віденським часом.

Сторона, що приймає:

- Привітання. "Ласкаво просимо. Христос воскресе!" Гості:

- Вітання у відповідь.

Сторона, що приймає:

- Формулювання приводу і цілі: "Ми зібралися на цю агапу напередодні Фоминої неділі на згадку про нашого Господа Ісуса Христа, Його прихід до Своїх учнів "незважаючи на закриті двері" і на підтвердження віри Фоми. Ми зібралися також, щоби підтвердити нашу любов один до одного в Ньому".

- Прохання про вибачення і надання миру: "Вибачте мене, друзі мої, за мої гріхи, які могли порушити наш світ і любов у Христі. Мир вам!"

Гості (всі разом):

- "Мир і вам, N!"

Один з гостей:

- "Сьогодні ми читаємо уривок з Євангелія від Іоанна, 20: 19-31".

- Читання Писання.

Гості та сторона, що приймає:

- Діляться думками про прочитане.
Сторона, що приймає:

- "Помолімося разом, як Господь навчив нас молитися".

Гості (всі разом):

- Читають молитву Господню "Отче наш".

Сторона, що приймає:

- "Отець N, не могли б ви благословити нашу їжу?"

- Усі тримають хліб і червоне вино перед камерою комп'ютера.

Отець N:

- "Христос Бог, поблагослови цю їжу і питво для Твоїх рабів, бо Ти святий нині і на віки віків".

Yci:

- "Амінь!"

Потім всі вживають їжу і ведуть бесіду.

У березні 2020 р., коли через карантинні заходи почали закривати для загального доступу храми, постало питання про те, як причащати вірян так, щоби не порушувати гігієнічні вимоги. У деяких парафріях їхні члени, яких священик добре знає і яким довіряє, отримали можливість брати часточки із собою додому і там ними причащатися в індивідуальному порядку. Така практика, однак, не стала масовою.

Масовішою, однак не домінуючою, стала практика причащати дарами у храмі, проте без використання літургійної лжиці. У таких випадках часточки євхаристійного тіла, насичені євхаристійною кров'ю, виносять на дискосі на амвон, і з амвона священник роздає їх у руки парафіянам. Це, по суті, $є$ повернення до давньої практики причастя, що в наш час збереглася у способі причастя для духовенства: у руку. Важливу роль у виправданні такої практики під час пандемії відіграло дослідження про візантійські літургійні лжиці, проведене о. Робертом Тафтом й опубліковане ним 1996 року. У цьому дослідженні його автор проаналізував матеріальні і текстові свідоцтва про використання лжиць у візантійській літургійній практиці і дійшов таких висновків. 3 огляду на їхню важливість для дискусій, пов'язаних із пандемією ковіду, ми наводимо їх тут повністю:

1. До сьомого століття древня традиція причащання в руки в деяких областях Сходу і Заходу починає скорочуватися через практику вкладання часток мирянам у рот. 3 IX ст. ми маємо свідчення про такий самий процес у візантійському обряді.

2. Хоча лжиці, які могли мати літургійне призначення, були виявлені в Сирії із IV ст., немає жодних доказів того, що такі лжиці так рано використовували саме для причастя.

3. Богослужбові лжиці існували задовго до того, як з'явилися свідчення про те, як саме їх використовували. Свідоцтва із Сирії та Палестини демонструють, що спочатку лжиці цілком могли використовувати для чогось іншого, окрім теперішньої візантійської практики причащання мирян. Найперше однозначне свідчення про саме таке використання лжиці у візантійській традиції не передує початку другого тисячоліття. Принаймні, один пізній документ Ульріха фрон Ріхентальського на початку XV cт. однозначно свідчить, що лжицю використовували для причастя візантійського духовенства із чаші.

4. Використання лжиці для причастя вперше було засвідчене в Палестині в VII ст. У зазначеному конкретному випадку лжицю, очевидно, використовували для причастя вищого духовенства. Як саме причащалися миряни - про це не повідомляють.

5. Візантійські джерела згадують літургійну лжицю, починаючи із другої половини IX ст. Однак лише у Гумберта Романського в середині XI ст. ми знаходимо недвозначний доказ їі використання для роздачі віруючим 
освяченого хліба, який перед тим був занурений у чашу і таким чином просякнутий освяченим вином.

6. До середини XI ст. нинішня практика причастя під обома видами за допомогою лжиці стала загальною, але не універсальною. Інші джерела свідчать, що продовжували існувати й альтернативні практики. За словами Патріарха Михайла II (1143-1146), деякі єпископи продовжували причащатися рукою. Вальсамон також має на увазі, що не всі церкви відмовилися від старої традиції вкладати віруючим обидва види причастя окремо і в руки [12].

Учениця о. Роберта Тафта інокиня Васса (Ларіна) у своїй доповіді на 24-й конференції Orientale Lumen, що відбулася онлайн у червні 2020 року, зробила важливе зауваження, яке випливає з практики причастя мирян за допомогою лжиці. Цю практику можна розглядати як ключовий момент того, що зазвичай називають структурами влади, а саме як символ влади кліру над мирянами. Відповідно, зміни цієї практики на більш демократичний спосіб причащання в руку багато хто в церкві як усвідомлено, так й інтуїтивно сприймає як загрозу існуючим структурам церковного авторитету.

Зазначену тезу можна узагальнити в тому сенсі, що внаслідок пандемії традиційні символи і практики ієрархічності в церкви опинилися під знаком питання. Крім необхідності переглянути спосіб причастя, ієрархи зіткнулися з необхідністю здійснювати богослужіння в мінімалістичному стилі: без іподияконів або навіть дияконів. Багато хто перейшов на служіння ієрейським чином.

На підставі наявних даних, які, звичайно, не є повними, можна зробити попередній висновок, що найбільше від ковіду постраждали ті помісні церкви, де ієрархизм у період перед пандемією досягав максимальних значень, як, наприклад, Російська або Сербська церкви. Менше постраждали більш демократичні помісні церкви, як, наприклад, Елладська або Кіпрська. Характерним, зокрема, є приклад Сербської православної церкви. 30 жовтня 2020 року в Чорногорії від ковіду помер місцевий сербський ієрарх Амфілохій (Радович). До цього він робив неодноразові заяви в дусі так званого ковід-дисидентства. Це скептичне ставлення до причин і наслідків захворювання на ковід, а інколи навіть сумніви в наявності самої загрози захворювання. Митрополит Амфілохій демонстративно зневажав заходи безпеки, коли, наприклад, у розпал епідемії організовував та очолював масові акції. У цих акціях також брав предстоятель УПЦ МП митрополит Онуфрій, який також прославився своїм ковід-дисидентством. Коли митрополит Амфілохій помер від ковіду, на його похоронах знову зібрався багатотисячний натовп, який у своїй більшості проігнорував норми профілактики зараження. Серед інших на похоронах був присутній предстоятель Сербської православної церкви патріарх Іриней (Гаврилович). Він, як і митрополит Іриней, раніше робив заяви в дусі ковід-дисидентства. Незабаром після відвідування похорону митрополита Амфілохія патріарх Іриней захворів на ковід, а 20 листопада 2020 року було оголошено про його смерть внаслідок ускладнень, викликаних коронавірусом.

В Україні своїми неадекватними заявами щодо ковіду прославилися предстоятель УПЦ МП митрополит Онуфррій та колишній очільник Київського Патріархату патріарх Філарет. Перший, зокрема, глузував із тих, хто сприймає загрози від пандемії серйозно. Під час святкувань 9 травня він зробив на телекамери таку заяву, що широко розійшлася в Україні та за їі межами:

Ми всі хворі - кожен має свою болячку. $Є$ люди, у яких піднімалася температура, потім знизилася температура, а завтра в іншого піднялася. Це життя. Це такий сезон переходу із зими на весну, і всі хворіють. А зараз, що не захворіло, то відразу підозрюють коронавірус: нога захворіла, вухо заболіло - коронавірус [1].

Патріарх Філарет зробив навіть радикальнішу заяву. У телепрограмі на 4 каналі він сказав таке: Епідемія це $є$ покарання Боже за гріхи людей. Причина коронавірусу - це гріховність. Відкрито добро не захищають, а захищають зло і розповсюджують його. Я маю, насамперед, на увазі одностатеві шлюби.

Він також заперечив можливість передачі вірусів через причастя:

Якщо ви вірите у те, що п'єте кров Христа, то це означає, що вірите в його життєдайну силу. Життя не може принести хворобу. Той, хто у це не вірить - то нехай не причащається [3].

I митрополит Онуфрій, і патріарх Філарет перехворіли на ковід. Їхні випадки підтвердили, що до коронавірусу однаково вразливі і ті, хто в нього вірить, і хто не вірить. Також вони підтвердили закономірність, що ковід-дисидентство $є$ сприятливим фактором для розповсюдження хвороби. Від ковіду більше постраждали ті релігійні осередки, де його найбільше ігнорували, зокрема у монастирях. Почаївська і Києво-Печерська Лаври, наприклад, стали гарячими зонами пандемії на її початку, про які широко повідомляли українські 3МІ. Менше відомо про менші монастирі, де теж перехворіла значна кількість ченців. Про це у $3 \mathrm{MI}$ майже не повідомляли, оскільки саме монастирі продемонстрували схильність приховувати інформацію про зараження.

Така тенденція пов'язана із певним тлумаченням захворювання на ковід. Згідно із цим тлумаченням, ковід це ознака слабкості віри та відсутності Божого благословення. Якщо хтось захворів на ковід, то на нього починають дивитися як ледь не на проклятого. Ідеться про стигматизацію хворих на ковід, які сприймаються як винуватці власної хвороби. Їхня провина полягає не в тому, що вони не досить ретельно дотримувався норм гігієни, а в тому, що недостатньо вірили та молилися.

Таке ставлення до ковіду нагадує давню практику визначення того, хто має рацію або винен, за допомогою так званих випробувань мукою. Це одна із форм "благочестивого насильства", розглянутих у дослідженні професора Каліфорнійського університету в Лос-Анджелесі Алана Пейджа Фіске і дослідника з Північно-західного університету в Іллінойсі Тейджа Шакті Рая [7]. У середньовічній Європі, як і в інших домодернових культурах, подібні випробування могли передбачати, наприклад те, щоб засунути руку в киплячий котел і витягти звідти перстень, або ж пронести на певну відстань у руках розпечене залізо тощо. Подібні випробування могли придумувати люди, а могла встановлювати природа. У будь-якому випадку потерпілого вважали винним і його вину підтверджував сам Бог. Для багатьох сучасних релігійних ковід-дисидентів коронавірус став подібного роду "випробуванням мукою".

Як короткий підсумок можна зауважити, що глобальна пандемія викликала різні, іноді полярні реакції в релігійному середовищі України та за її межами. 3 одного боку, вона посилила фундаменталістські тенденції та конспірологічні теорії. На жаль, ці тенденції і теорії зробили тих, хто їх дотримується, вразливішими до коронавірусу і небезпечними для оточуючих. 3 іншого боку, ризики, пов'язані з пандемією, сприяли плідній дискусії щодо таїнств церкви та їхніх богословських засад. Пандемія створила потужний імпульс для процесів катарсису й емансипації всередині українських церков.

Список використаних джерел

1. Онуфрий о количестве заболевших коронавирусом в Лавре: Мы все больны [Электронный ресурс] : видео : мат. Лига-новости від 9 трав. 2020 р. - Режим доступа : https://tinyurl.com/y3ffcvcw (8 груд. 2020 р.). 
2. Отець Ігор Сава: Господь відповідає на Євхаристійну молитву дистанційно на кожній літургії [Електронний ресурс] : публікація 16 трав. 2020 р. - Режим доступу : https://tinyurl.com/y5j653ms (6 груд. 2020 р.).

3. Програма "4esno з Ташею Трофимовою" від 19 берез. 2020 р. на 4 каналі [Електронний ресурс]. - Режим доступу : https://tinyurl.com/ tdvxnak (8 груд. 2020 р.).

4. Публікація від 11 травня 2020 р. [Електронний ресурс]. - Режим доступу : https://tinyurl.com/yxpvg3ol (6 груд. 2020 р.).

5. Філарет заявив, що гомосексуалізм став причиною коронавірусу [Електронний ресурс]. - Режим доступу : https: //news.24tv.ua/filaret zayaviv_shho_gomoseksualizm_stav_prichinoyu_koronavirusu_video_n13 02109.

6. Що не так у онлайн-причасті? [Електронний ресурс]. - Режим доступу : http://www.kiev-orthodox.org/site/worship/7219.

7. Fiske Alan Page. Virtuous Violence: Hurting and Killing to Create, Sustain, End, and Honor Social Relationships /Fiske Alan Page and Rai Tage Shakti. - Cambridge : Cambridge University Press, 2014. 384 p.

8. Hovorun Cyril. Will, Action and Freedom: Christological Controversies in the Seventh Century / Cyril Hovorun. - Leiden ; Boston : Brill, 2008. - P. 28-29.

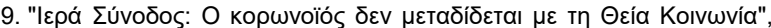

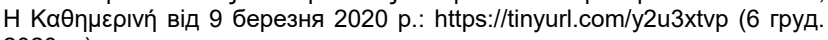
2020 p.)

10. McGowan A. Naming the Feast: The Agape and the Diversity of Early Christian Meals / A. McGowan // Studia Patristica. - 1997. - 30. P. 314-318.

11. McGowan A., "Rethinking Agape and Eucharist in Early North African Christianity / A. McGowan // Studia Liturgica. - 2004. - 34). P. 165-176.

12 Taft Robert F. Byzantine Communion Spoons: a Review of the Evidence / Robert F. Taft // Dumbarton Oaks Papers. - 1996. - 50. - P. 238

13. Terence Penelhum. Fideism / Terence Penelhum // A Companion to Philosophy of Religion / Charles Taliaferro, Paul Draper, and Philip L. Quinn (eds). - John Wiley \& Sons, 2010, - P. 441-448.

14. T\&T Clark Handbook to Early Christian Meals in the Greco-Roman World / ed. by Soham Al-Suadi and Peter-Ben Smit. - L. : T\&T Clark Handbooks, 2019. - 189 p.

\section{References}

1. "Onufrii o kolichestve zabolevshikh koronavirusom v Lavre: My vse bolny - video" [Onuphrius on the number of coronavirus patients in the
Lavra: We are all sick - video]. Liga-novosti from May 9, 2020. https://tinyurl.com/y3ffcrcw (December 8, 2020).

2. "Otecz' Igor Sava: Gospod' vidpovidaye na Yevxary'stijnu moly'tvu dy'stancijno na kozhnij liturgiyi", published on May 16, 2020. https://tinyurl.com/y5j653ms (December 6, 2020).

3. The program "4esno with Tasha Trofimova" from March 19, 2020 on Channel 4. https://tinyurl.com/tdvxnak (December 8, 2020).

4. Publication of May 11, 2020. https://tinyurl.com/yxpvg3ol (December $6,2020)$.

5. Filaret zayavy'v, shho gomoseksualizm stav pry'chy'noyu koronavirusu [Filaret stated that homosexuality was the cause of the coronavirus:] https://news.24tv.ua/filaret zayaviv shho gomoseksualizm stav_prichinoyu_koronavirusu_video_n1 $\overline{302109}$.

6. "Shho ne tak u onlajn-pry'chasti?" ["What's wrong with online communion?"]. http://www.kiev-orthodox.org/site/worship/7219.

7. Alan Page Fiske and Tage Shakti Rai, Virtuous Violence: Hurting and Killing to Create, Sustain, End, and Honor Social Relationships, Cambridge: Cambridge University Press, 2014. 384 p.

8. Cyril Hovorun, Will, Action and Freedom: Christological Controversies in the Seventh Century, Leiden; Boston: Brill, 2008, 28-29.

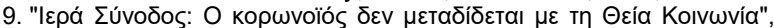

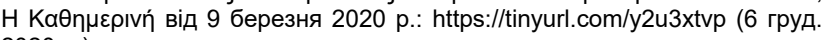
2020 p.).

10. McGowan A., "Naming the Feast: The Agape and the Diversity of Early Christian Meals." Studia Patristica 30 (1997): 314-18.

11. McGowan A., "Rethinking Agape and Eucharist in Early North African Christianity." Studia Liturgica 34 (2004): 165-76.

12 Taft Robert F., "Byzantine Communion Spoons: a Review of the Evidence." Dumbarton Oaks Papers 50 (1996): 238.

13. Terence Penelhum, "Fideism." Charles Taliaferro, Paul Draper, and Philip L. Quinn (eds). A Companion to Philosophy of Religion, John Wiley \& Sons, 2010, 441-448.

14. T\&T Clark Handbook to Early Christian Meals in the Greco-Roman World. Edited by Soham Al-Suadi and Peter-Ben Smit. T\&T Clark Handbooks, London: T\&T Clark, 2019, 189.

Надійшла до редколегії 03.11.20

К. Говорун, д-р филос. наук, проф.

Стокгольмская школа теологии, Стокгольм, Швеция

\section{ДОБРЫЕ И ЗЛЫЕ БОГОСЛОВСКИЕ ПЛОДЫ ПАНДЕМИИ}

Исследованы различные подходы к пандемии COVID-19 как в мировом, так и в украинском православии, в частности, проведено различие между фидеистическим и реалистическим подходами к евхаристии и передаче через нее вирусов. Первый подход отвергает, а второй - утверждает риск заражения коронавирусом через причастие. Обсуждены различные возможности и формы совериения богослужения в интернете, включая противоречивую практику проведения литургии через коммуникационные платформы. Предложено обновленную форму древней агапы - "трапезы любви", которая сопровождала евхаристию в ранней церкви. В ней также упоминаются древние и современные формы раздачи причастия, с особым упором на исследование отца Роберта Taфma, SJ. Eще одна тема, обсуждаемая в статье, - это так называемое ковид-диссидентство, когда люди недооценивают или игнорируют риски и меры по предотвращению распространения инфекции. Такое диссидентство популярно среди православных фундаменталистов и консерваторов, в том числе и в Украине. Особое внимание уделено двум случаям ковид-диссидентства - бывших киевских митрополитов Онуфрия (Березовского) и Филарета (Денисенко). Статья содержит утверждение, что отношение к ковид-19, которое демонстрируют эти и некоторые другие иерархи, похоже на средневековые "испытания страданиями", когда подозреваемых в преступлениях, например, заставляли выловить кольцо из кипятка или пронести горячее железо. Их считали невиновными только тогда, когда те выходили из испытаний неповрежденными. Утверждаем, что подобное отношение к пострадавшим от COVID-19 ведет к их стигматизации.

Ключевые слова: евхаристия, фидеизм, ковид-19, агапа, испытания страданиями, фундаментализм.

Cyril Hovorun, Dr Hab., Prof.

Sankt Ignatios College, Stockholm, Sweden

\section{GOOD AND EVIL THEOLOGICAL FRUITS OF THE PANDEMIC}

The article explores various approaches to the Covid-19 pandemic in both global and Ukrainian Orthodoxy. It in particular differentiates between the fideistic and realistic takes on the Eucharist and the transmissibility of viruses through it. The former rejects, and the latter affirms the risk of getting infected with coronavirus through partaking in holy communion. The article also discusses various possibilities and forms of worshipping online, including the controversial practice of celebrating liturgy through communication platforms. The article suggests an updated form of the ancient agape--the meal of love that accompanied Eucharist in the early church. It also mentions the ancient and modern forms of the distribution of communion, with a special reference to the study by Fr Robert Taft, SJ. Another topic discussed in the article is the so called "Covid dissent," when people undermine or dismiss the risks and measures to prevent the spread of the disease. This dissent is popular among the Orthodox fundamentalists and conservatives, including the ones in Ukraine. The two cases of the "Covid-dissent," articulated by former Metropolitans of Kyiv Onufriy Berezovsky and Filaret Denysenko, are in the focus of the study. The article argues that the attitude to Covid-19 that these and some other hierarchs promote, is similar to the medieval "trials by ordeal," when suspects were ordered to fish a ring from boiling water or carry hot iron. They were regarded innocent only when they remained unharmed by these tests. The same attitude, the article argues, leads to stigmatization and victimization of those who have suffered from Covid-19.

Keywords: Eucharist, fideism, Covid-19, agape, trial by ordeal, fundamentalism. 